\title{
3 The nationalism of the New Right in the Federal Republic of Germany
}

\author{
Marek Maciejewski
}

\section{Introduction}

The far right has played an important role in the shaping of nationalist tendencies in some of the political environments of the Federal Republic of Germany (FRG). The authors of academic papers on this topic also use other names for this political phenomenon, chiefly the concepts of the extreme right and the radical right. ${ }^{1}$

At this point, it should be noted that the aforementioned terms do not always accurately describe the political character of the groupings that are so named as they are sometimes closer to values that are considered to be more left than right wing. Perhaps a more accurate description of the representatives of the far right would be as 'left-wing people from the right-wing', according to the terminology suggested by the German researcher Ernst-Otton Schüddekopf in $1960 .^{2}$ My doubts regarding the validity of using those terms seem to be confirmed by the political concepts of one of the main far-right trends in the FRG, namely the New Right (Neue Rechte). The ideology, organisation and work of this far-right faction is discussed in this chapter. In this introduction, one should also state that the New Right (NR) is different from the 'old', conservative and even liberal right represented in the FRG, at least partially, by the CDU, CSU and FDP, due to its nationalism, anti-democratism, as well as populism and elements of a left-wing world view. One of the most important distinctive features of this far-right trend - using the name NR with some reservations - is undoubtedly nationalism, usually connected with the adjective 'new', since it is different at some points from the pre-1945 German nationalism. ${ }^{3}$ The new nationalism of the New Right is not as dangerous, primitive and aggressive as the nationalism of the Weimar Republic, and the Third Reich in particular, which does not mean that it poses no danger to the constitutional order of the FRG, and even for other European countries, including Poland. 


\section{The genesis of the phenomenon}

In terms of the origins of the NR, it began to shape itself shortly after the Second World War, and was a significant and influential political movement at the end of the 1960s and in the 1970s. It was connected, among others, with the effects of the revolt of young people in the West and the crisis of capitalism at that time, which turned out to be also inspiring, or even more inspiring, for the development of the New Left. At the end of that century, and at the beginning of the 21st, the NR experienced a structural and intellectual crisis after its time of flourishing. The NR has been shaped mostly in the RFG and France, but it has also developed - to a lesser extent - in the UK and the USA, and for several years it has manifested some political activity in Russia, where, nota bene, the theory of the former 'crown jurist' of the Third Reich, Carl Schmitt, has experienced something of a renaissance. In all those countries, but mostly in Germany and France, the New Right bases its concepts and activity primarily on the pre-war nationalist and anti-democratic doctrine of 'conservative revolution' (Konservative Revolution) in the Weimar Republic, adapted to its current propaganda goals. After the Second World War, the NR also brought its own political and social concepts to the extreme right ideology, which were more appropriate to contemporary times. However, according to the FRG scientist, Hans Gerd-Jaschke, the concepts of the German NR are not original, since they are mostly based on the ideas of the French new right representatives (A. de Benoist et al.). ${ }^{4}$ However, it does not seem that the influence is only one-sided in this matter.

In Germany, reunited since 1990, the NR is one of the four elements of right-wing extremism - beside its national-democratic direction (Nationaldemokratische Partei Deutschlands - NPD), national-liberal parties (Deutsche Volksunion mostly, but also die Republikaner) and neoNazi groups (which are small and ephemeral - recently, mostly the so-called Kameradschaften). The NR dominates the remaining far-right trends in the FRG with its political programme, although not always with the originality of its views, giving ready ideological solutions to the related groups that they eagerly use in their propaganda. However, it is usually weaker when it comes to organisation, since it mostly takes the form of associations, discussion clubs or individual publishing houses rather than actual political groups, let alone political parties. Just like pre-war revolutionary conservatism, the NR is above all an intellectual trend. Its origins in Germany can be traced back to the polarisation of the positions of the right-wing forces in Germany at the turn of the 1940s and 1950s regarding the assessment of Nazism in the history of the country. ${ }^{5}$ It was then that the division into supporters of the 'old' nationalism, i.e. the former right wing which drew on the legacy of National Socialism and looked for its inspiration in the model between the NSDAP and the right-wing nationalist Volkspartei Deutschnationale at the end of the Weimar Republic, and the advocates of a 'new' nationalism, free of this historical burden, took place. Although the NR tried to cut itself off 
from the Nazi past, it did not fiercely condemn everything Nazi, seeing some positive aspects in it such as the elimination of unemployment, the development of industry, the state's care for social issues, etc. According to Uwe Backes and Eckhard Jasse, this new nationalism - as a distinguishing feature of the earlier revolutionary conservatism - became the origin of the NR movement. This nationalism began after the Second World War, in 1949, when Anton Hausleiter founded the Deutsche Gemeinschaft (DG), whose goal was to transform Germany into a 'neutral central block between East and West'. ${ }^{6}$ DG developed the concept of a 'third way', which meant a call for Germany to oppose the hegemony of two superpowers in Europe: the USA and the USSR.

In order to consolidate the new right, in 1965, Hausleiter established an organisation called Aktionsgemeinschaft Unabhängiger Deutscher with around 2,500 members. In the early 1970s, it was transformed into a 'life protection party', referring to another element of the NR worldview, namely its attachment to the principles of ecology that were formed at that time. The assumptions of this organisation were based on the anti-civilisation, catastrophic worldview of the philosopher Oswald Spengler, who was counted among the pre-war revolutionary conservatives. Among the groups that formed the foundations of the NR in Germany it is still necessary to mention the Deutsch-Soziale Union (DSU) founded in 1956 by the former opponent of Adolf Hitler, Otto Strasser, as a 'synthesis of freedom and justice'. ${ }^{7}$

Like other right-wing organisations, this group turned out to be ephemeral, and in 1962 it transformed itself into the Unabhängige Arbeiter-Partei (UAP), which, without much social resonance, proclaimed the concept of a solidarity-based German national community (Volksgemeinschaft). It was no stranger to the reformist views of the 19th century socialist Ferdinand Lassalle. The DSU and the UAP constituted the link preceding the shaping process of the proper NR in Germany.

On the way to the formation of this right-wing extremism, other organisations appeared in the 1950s. One of them was Bund Nationaler Studenten (1956), which ran a both anti-communist and anti-capitalist magazine Nation Europa addressed to young readers, who were no longer entangled in the Nazi past of their nation. In the magazine, young neoright representatives (including Peter Dehoust, Martin Mussgnug and Peter Stöckicht) popularised the nationalist views of the 'father' of the European NR, Julius Evola, the French extreme right-wing theorist Maurice Bardèche or the leader of British fascists, Oswald Mosley, ${ }^{8}$ among others.

The talented columnist Henning Eichberg started to cooperate with the magazine; unlike others on the neo-right, he was generally sceptical about the usefulness of the ideology of pre-war revolutionary conservatism in the shaping of the NR. At the beginning of the 1960s, the FRG intensified its efforts to broaden its organisational and journalistic neo-right activity. It is worth noting that even before the youth protests of 1968 , the following 
magazines were created: Missus by Hans-Michael Fiedler, 'Fragmente' by Gert Waldmann and Junges Forum by Johann Penz. Their aim was to oppose the old right wing - CDU and CSU - as well as the critique of parliamentary democracy in the FRG through 'spiritual regeneration combined with moral renewal of our nation and homeland shamefully split in two by the AmericanSoviet conspiracy'. Like many other political forces in West Germany, the NR never came to terms with the consequences of the military defeat of the Reich in 1945. This is also exemplified by the 1964 programme appeal of the farright organisation Initiative der Jugend, whose main slogan was: 'German neutrality - unity and freedom for the nation'. The criticism of the Yalta-Potsdam order expressed in these words was used by right-wing extremists in the early 1970s in their 'resistance action' (Aktion Widerstand) against the agreements aiming at normalising the FRG relations with its eastern neighbours. The action of resistance against these treaties, however, was not directed against the Polish or Czech nations, but against the 'imperialism of the USA and the USSR'. ${ }^{9}$ According to Penz, both of these countries were 'the perpetrators of a great tragedy of all Europe' after the Second World War, and not just 'the humiliation of German dignity and national pride' (1972). At the turn of the 1960s and 1970s, some NR groups (including Aussenparlamentische Mitarbeit and Volkssozialistische Bewegung Deutschlands) even called for the solidarity and cooperation of all oppressed European nations.

\section{Developments from the end of the 1960s}

The breakthrough moment in the formation of the NR in Germany was the aforementioned student revolt of 1968, which coincided with the social-liberal coalition coming to power. The increase of political activity of the socalled new nationalists competing for political influence with the New Left, inspired, among others, by Herbert Marcuse, was manifested by the spontaneous establishment of 'base groups' (Basisgruppen) at universities with 15-20 members each (including Republikanischer Studentenbund in Bochum and the Symenenko Club in Munich). An important event in the development of the NR was also constituted by the political arguments in the leadership of the NPD after the Bundestag elections of 1969. As a result of those disputes, the party collapsed in 1972 and Siegfried Pöhlmann founded the organisation called Aktion Neue Rechte (ANR) with around 450 members. ${ }^{10}$ Its programme, referring to the 'nationalism is progress' slogan that was then popular in radical right-wing circles, can be described as national-revolutionary, and therefore in fact closer to the left than to the right. ANR was in favour of a 'German revolution', 'solidarity of the national community' and 'democracy of freedom'. Like many other NR groups, this organisation turned out to be ephemeral. In 1974, in Wurzburg, the Nationalrevolutionäre Aufbauorganisation (NRAO) emerged and it was later joined by another small group named Sache des Volkes. A pre-war revolutionary conservative, Ernst Niekisch, known for promoting the idea of the German-Soviet alliance, 
became their ideological patron. However, some of the NRAO activists did not mind proclaiming slogans postulating a completely different alliance, namely the cooperation of European national-revolutionary forces with communist China, aimed at ending the world hegemony of the USSR and the USA. Thomas Schulze and Udo Reinhardt, the editors of the neo-right Freiheit magazine, often spoke out against this hegemony in the 1970s and 1980s. It is worth mentioning that the national revolutionary circles of the NR liked and appreciated the establishment and activity of the NSZZ 'Solidarnośc' (Solidarity). In connection with the 1980 and the subsequent banning of the independent labour movement in communist Poland, the slogan 'Better to die standing than to live on one's knees' appeared in the publications of this NR trend in FRG.

Regarding the further development of the NR with a national revolutionary ideology, the establishment of the Solidaristische Volksbewegung in Hamburg in 1974, which a few years later became the Bund Deutscher Solidaristen, should also be mentioned. From the beginning of the 1980s, the quarterly Aufbruch began to be considered the leading voice of this part of the neo-right. Its anti-liberal, ecological, populist and political profile was supposed to attract the supporters of the so-called third way of German development to the NR. The third way was based on two main assumptions: new nationalism and socialism with nationalist elements. ${ }^{11}$ Although those on the national-revolutionary neo-right criticised the Soviet Union, the editors of Aufbruch did so only in moderation (also with regard to the Soviet Union's policy towards Polish affairs after the creation of the NSZZ 'Solidarność'), speaking more negatively about the USA. Undoubtedly, this branch of the NR was characterised more by anti-capitalism than anti-communism. Also, in the 21st century, the national-revolutionary representatives of the extreme right in Germany - although the Soviet Union no longer exists - still use the political rhetoric from decades ago. In recent years, they have even gained some popularity because of the anti-Americanism spreading in Germany, especially in connection with the US war against Saddam Hussein's regime in Iraq in 2003 and the subsequent international armed conflicts in the world (Afghanistan, Syria and others).

However, another neo-right magazine published since 1970 by Caspar Schrenck-Notzing and Armin Mohler in Munich, Criticòn, cannot be described as clearly anti-capitalist. It became a theoretical guiding light, especially for members who were less radical the national revolutionaries of the NR in terms of social issues and whose goal was to give up populist slogans and build an elite model of power and society, among others. From the outset, Criticòn also proclaimed the idea of bringing the West German neo-right closer to its French counterpart, Nouvelle Droite. ${ }^{12}$ Other West German neo-right activists, including the Nationalistische Front founded in 1985 under the leadership of Meinolf Schönborn, also cooperated with the French NR and similar political forces in other countries (including Belgium and Spain). After the organisation was banned in 1992, it was transformed 
into the Sozialrevolutionäre Arbeiterpartei, continuing some elements of the 1979-created Freiheitliche Deutsche Arbeiterpartei (FAP) propaganda, including the 1920 Nazi party's programme 'The common good before selfgood' (Gemeinnutz vor Eigennutz). The views of FAP activists against economic liberalism principles were sometimes combined with anti-Semitic concepts. The editors of the aforementioned magazine 'Nation Europa' spoke in the same vein. More recently, the magazine has started to focus on the currently fashionable and propagandistically exploited issues of environmental protection.

\section{Ideological and propaganda assumptions}

Returning to the theoretical assumptions of Criticon, the concepts of the pre-war revolutionary conservative current called 'Young Conservatism', represented by Arthur Moeller van den Bruck, Edgar J. Jung, Carl Schmitt and Oswald Spengler, turned out to be popular in the circles associated with this magazine. Mohler was the epigone of this direction. Other publishers (Sinus Verlag and Herder Verlag) and associations (Verein zur Förderung Konservativer Publizistik or Verein zur Förderung Kultur- und Sozialwissenschaftlicher Publizistik) cultivating the achievements of the 'conservative revolution' further succoured Criticòn. At that time, Herder's publishing house in particular made a significant contribution to the promotion of the neo-right worldview, which, among other things, thanks to the conservative German author Gerd-Klaus Kaltenbrunner, focused on the issues of the German national community considered in terms of 'liberating nationalism' (Befreiungsnationalismus). ${ }^{13}$ As early as the 1970s, the aspiration to present more recent German history in such a way as to 'overcome the past' burdened with the crimes of the Nazi period became apparent in the texts published by this publishing house. The efforts of a part of the NR to re-evaluate the assessments of this stage of the history of its own state and nation somehow influenced the content of the dispute (the so-called Historikerstreit) on the uniqueness of Nazi totalitarianism, heated in the mid-1980s among West German scholars and publicists. From the neo-right circles of researchers, several scientists (including the political scientist Hans J. Arndt, historian Hellmut Diwald, sociologist Robert Hepp, philosopher Günther Rohmoser, political scientist Bernard Willms) joined the fierce discussion on this issue and tried to undermine the exceptional nature of Nazi crimes. ${ }^{14}$

The national question turned out to be such an inspiring and demanded topic of both scientific and political discussions, even before 'Historikersreit', that in 1979, NR ideologists decided to issue in Kolbenz a new nationalist magazine called Wir selbst. A year later, a new magazine named Deutschland in Geschichte und Gegenwart, published by Pierre Krebs connected with Grebert Verlag, joined the trend of promoting a new look at the history of the Third Reich. In the 1980s, Krebs was also the initiator of other neo-right editorial 
and organisational enterprises. One of his political activities was the association Thule-Seminar, created in 1980 who proclaimed the slogan 'Germany for Germans' (Deutschland den Deutschen). In 1987, the same nationalistic and xenophobic ideological assumptions were the basis for the 1986 magazine Elemente, based on the French neo-right periodical of the same name. In 1987, Krebs included the political credo of the then NR in Germany, namely freeing Europe from the domination of the USA and the USSR, restoring the national and cultural identity of this continent, developing its cooperation with the countries of the so-called Third World and working out a third way for the social development of Europe..$^{15}$ Most of these slogans have not lost their relevance in the new political situation on our continent after the break-up of the Soviet bloc in the early 1990s. Some of them became even more meaningful than before - due to the growing nationalistic and separatist tendencies in Central and Eastern Europe at the end of the 20th century, a growing fear of proletarianisation, the ineffectiveness of democratic ways of governing, etc.

\section{The influence of German reunification}

The NR activity in the FRG, as well as other political phenomena in Germany - were undoubtedly influenced by the reunification of Germany in 1990. As already mentioned, the fact of reunification did not cause a significant growth in the importance of the neo-right, although an increase in its political activity was visible in the first years after reunification. It was mostly their quest for power that ideologically inspired the neo-Nazis, who, at that time, became a severe threat to public order, through their violent behaviour towards foreigners, among others. They had not ceased being a threat - although perhaps to a lesser extent - by the turn of the 20th and 21 st centuries. In terms of the NR, at the beginning of the 1990s, it gained unexpected support from a section of the members of CDU - the governing party. In 1992, 192 members of CDU founded the Christlich-Konservatives Deutschland-Forum (CKDF), which followed the example of pre-war revolutionary conservatism. The formation cooperated with the neo-right magazine named Junge Freiheit. ${ }^{16}$ The periodical propagated, among others, the concepts of 'German Socialism' created by Werner Sombart in the first half of the 20th century, which called for the mobilisation of the German nation against some external danger, 'the ideas of 1914' by Johann Plenge and even the views on the advantages of the 'dictatorship of the sabre' developed by the 19th century Spanish conservative Juan Donoso Cortes. ${ }^{17}$

One of the most active propagators of the NR at that time was Günter Maschke - an admirer of Moeller van den Bruck, Spengler, Schmitt and several other revolutionary conservatives. Thanks to his political contacts, the CKDF managed to create a couple of small discussion clubs (including Potsdamer Kreis, Karlshorster Kreis, Petersberger Kreis) under the catchy slogan 'Everything for Germany'. Most of them, however, did not survive 
the turn of the 20th and 21st centuries. Although these small NR associations were replaced by new organisational or journalistic formations (e.g. 'Neue Alternative für Deutschland', 'Unsere Zukunft' or 'Neukonservative Freiheitsbewegung'), they no longer play such an opinion-forming and political role as they did years ago or have even become inactive. Although the period of NR's greatest development in Germany has passed, its philosophical and ideological assumptions have not changed. They are still attractive to the part of German society (especially its young generation) which supports nationalist and even racist and anti-democratic ideas. As early as 1998, far right-wing ideas - coloured, after all, by socialist elements - were accepted by $15 \%$ of young people in the West and as many as $23 \%$ of young people in the East of Germany (the former GDR).$^{18}$ At that time, more than half of young German citizens also declared their dissatisfaction with both the political and social systems of their country. At the beginning of this century, little has changed in this respect, especially in connection with the considerable and largely uncontrolled influx of refugees from Arab countries and Africa into Germany from 2015. The NR perceives this process as a serious threat to Germany's national identity.

\section{A word on its doctrinal foundations}

Both the doctrinal and propaganda aspects of the NR in Germany after the Second World War comprise different philosophical, political and social concepts. Many of them have been either directly or indirectly borrowed from other idea creators since the early Modern period up until the 20th century. Apart from the ideas of pre-war revolutionary conservatives, who were particularly appreciated by the NR, and the aforementioned Julius Evola, the NR was inspired by the concepts of Niccolo Machiavelli, the immoralist and nihilist Friedrich Nietzsche, syndicalist Georgesa Sorel, the anti-democrats Josè Ortega y Gasset and Charles Maurras, zoologists Konrad Lorenz (Nobel Prize laureate) and Irenäus Eibl-Eibesfeldt, psychologist Gustave le Bon and the historians of religion Georges Dumèzil, Mircea Eliade and Louis Rougier. The concepts were often juxtaposed quite accidentally. The neo-right theoreticians sometimes also draw on the achievements of left-wing thought, especially the views of the cultural communist Antonio Gramsci and JeanPaul Sartre, who was himself charmed by Marxism. In ideological terms, the NR in Germany shows a certain similarity to the so-called technocratic conservatism which had been developing in the country even before the reunification of Germany and the GDR, represented by Ernst Forsthoff, Hans Freyer and Arnold Gehlen, among others. ${ }^{19}$ However, in general, the NR does not accept the admiration of these ideologues for contemporary technical achievements, but appreciates instead the nationalist premises of their views on society and the state. Although the NR appeals to the indicated ideological legacy, partly building its doctrine on it, it rejects the pessimistic assumption that all values (truth, absolute, sense of life, etc.) are relative and do not exist 
in reality - apart from politics, natural social hierarchy and some elements of tradition.

The elements forming the core of neo-right thought include a conglomerate of various slogans and postulates that do not always form a cohesive whole. They all serve a single propaganda purpose: to convince the broadest possible circles of German society which are dissatisfied with the policy of the FRG authorities for various reasons, of the legitimacy of the NR and to criticise those in power from the position of right-wing, anti-democratic radicalism. Therefore, it is unsurprising that in the ideological arsenal of the neo-right one can find, for example, a view on the decadence of Western civilisation in the 20th century, modelled on the aforementioned theory of Spengler. As in revolutionary conservatism, it corresponds to a strongly resounding anti-liberalism, slightly less exposed anti-communism, or to the preferred anti-egalitarianism. A new, i.e. all-German, nationalism 'for all' comes to the fore as a basic trigger for social and political life, and sometimes also racism with antiSemitic overtones or hostility to so-called aliens - mainly Islamic migrants. In order to avoid any overt references to Nazi propaganda, the above-mentioned components of NR thought are usually hidden under the modern, 'sciencesounding' terms of bio-humanism and ethnopluralism. Added to this is an only slightly camouflaged and mystified neo-paganism (belief in a Germanic religion and myths, negation of Christianity, etc.). The neo-right is also characterised by the belief that politics reigns supreme over the economy, culture and all other areas of public life. As for the first of the listed elements contained in this ideological catalogue, i.e. the negation of Western values, it should be noted that it stems from the NR's fundamental criticism of the philosophy of the Enlightenment and the French Revolution at the turn of the 18th and 19th centuries. Just like the representatives of the NR in France, those on the German neo-right (e.g. Henning Eichberg and Gerd Waldmann), confront a liberal revolution with a revolution with national characteristics, i.e. pit 'a revolution against a revolution'. They accuse the 'progressive revolution' of creating human and civil rights that contradict the natural diversity of people and are based on -according to those on the neo-right - a false principle of equality and identicality. They perceive the spread of the concept of these rights as a manifestation of 'ideology for pensioners', which should be replaced by the assumptions of a more modern form of 19th-century social Darwinism, i.e. an aetiology assuming similarity of human and animal behaviour. ${ }^{20}$ According to Waldmann, it is enough to study zoopsychology to understand the real motives of human behaviourism: the struggle for species survival, for food and for own territory. They give rise to the natural need to conduct wars as, among others, 'a regulator of excess population in the world'.

This concept of human beings, also presented by the NR outside of Germany, is based on racial premises, although they are not exposed as clearly as in Nazi or neo-Nazi ideology. However, those on the neo-right in Germany (e.g. Waldmann) consider the consolidation of polygamous 
divisions, especially between the white and black races, to be a necessary condition for proper historical development. Therefore, the concepts of proxemics are popular among the NR theorists, i.e. the science of the relationship between a specific culture and the area and time of its development. ${ }^{21}$ Using the term 'ethnopluralism' to divide human races into better and worse ones, representatives of the neo-right eagerly seek confirmation of the validity of this thesis in the results of the IQ test commonly used in the West after the Second World War. It replaced the anthropological and eugenic studies of races carried out previously, especially in the Third Reich. For understandable reasons, the NR attributes the highest intelligence quotient to the members of its nations: Germans, French and others - although not all of them. Neoright representatives consider Jews to be a negation of the high intelligence of Germans or other Western nations less frequently than 'classic' Nazi and neo-Nazi racists, although the NR doctrine is by no means free from antiSemitic sentiment. Jews are blamed, among others, for the development of the capitalist relations it criticises. ${ }^{22}$ The NR's postulate that the state should conduct a proper 'biopolitics' towards terminally ill persons, criminals and the socalled anti-social elements does have a racist background. For this purpose, even the use of euthanasia is not ruled out and, in relation to particularly valuable people, the use of the latest achievements of embryology (cloning of human genes). All this is intended to achieve one goal - to breed a new type of Nietzschean 'superhuman': a healthy, strong, and intelligent German or Frenchman, who would belong to the elite of their nation as a representative of the so-called meritocracy. ${ }^{23}$ They should also be able to free themselves from the 'slave principles of Jewish-Christian religion and morality' (Waldmann) that hinder their development. In this area, the NR is looking for models to follow in the pagan faith and the culture of ancient Greece and Rome.

As far as social matters are concerned, it advocates increasing state interventionism in an economy with modified capitalist features (e.g. by increasing the share of employees in the management of production and service plants), without demanding - with few exceptions - the abolition of private property. The future social system is imagined as a corporate system functioning on the principle of solidarity between employers and employees united by common national goals. The NR is not alien to the views of some left-wing thinkers in this field: the aforementioned reformer Ferdinand Lassalle, syndicalist Georges Sorel and even anarcho-individualist Pierre Proudhon. Following the example of pre-war revolutionary conservatives (especially Ernst Jünger), it encourages the 'total mobilisation' of the German people in order to bring about continuous improvement in their material situation. In its social views, it also stresses the need to 'spiritualise' the economy by eliminating the 'merchant spirit' from public life. However, it should be noted that for the NR, social relations - unlike national issues - have never constituted a fundamental doctrinal problem. In any case, they have not received a comprehensive formulation in the confines of this ideology. 
The NR in the FRG focuses more on the issues of the political system. From its inception to the present day, it has been an advocate of authoritarian rule, although it does not criticise parliamentary democracy as fiercely as its precursors - the revolutionary conservatives, not to mention the Nazis. A model for the neo-right in this field is the doctrine and practice of Bonapartism, i.e. a plebiscite dictatorship that combines elements of the actually limited power of a charismatic leader with elements of direct democracy, sometimes referred to in NR ideology as organic democracy. As I have already mentioned, in matters of the political system, it willingly refers to Carl Schmitt's concept, and especially to his theory of sovereignty. Let me recall here that, according to this lawyer, the actual, and not only constitutional, sovereign is the one who 'decides on the state of emergency'. ${ }^{24}$ Schmitt's admirer, the aforementioned Mohler, modified this view in 1988. In his opinion, at the end of the 20th century, which was characterised by conflicts on a global scale, the real sovereign is the one who decides on the use of atomic weapons. ${ }^{25}$ As for the political doctrine of the NR, due to its nationalistic and anti-liberal assumptions, it is critical of the issue of European unity. Instead of fully integrating the continent, it advocates loose federal ties between individual states - with a clear preservation of the national and cultural identity and distinctiveness of European countries. For this reason, it was negative towards the Maastricht Treaty (1992), perceiving the European Union as a new kind of bureaucratic and cosmopolitan hegemony, and even a totalitarianism of sorts on our continent. It is no wonder that the NR, also outside of Germany, is critical of the process of enlarging the Union to include new members. What is more, it opposes such 'irresponsible actions' which will result in 'our continent ceasing to constitute an intrinsic value' and becoming 'a mass of atomised people, unrelated to each other in mutual relations - except for exuberant consumerism and hedonism' (Waldmann).

In terms of this issue, as well as a number of other political or social matters, it is driven primarily by the criterion of German national interest that is referred to constantly in its political rhetoric. Its far-reaching nationalist goals were already revealed in the magazine entitled Nation Europa, which was established early in the second half of the 20th century by former members of the Nazi SS. They referred to the ideas of Imperium Germanicum or Imperium Teutonicum, which were close to those of the pre-war German revolutionary conservatives, and even to the concepts of the so-called Central Europe (Mitteleuropa) by Friedrich Naumann. All these political ideas were integrated by one essential belief - that it was necessary to ensure Germany a leading, even hegemonic role on the Old Continent. This is the only way for the NR to recognise the implementation of the idea of a common Europe, although in general it does not explicitly articulate its imperialist goals and is officially critical of it. Instead, it tries to emphasise Germany as the cornerstone of the current economic power of the European Union. It seems somewhat obvious what lies behind such a move. Since the European Union is 
already functioning, let Germany have the greatest influence on this organisational structure, and even let Germany determine - primarily in its own interest - the methods of its operation and directions of further development.

\section{Conclusions}

It should be restated that the new nationalism, as a keystone of the ideology and propaganda of the NR, makes this trend of the extreme right attractive to those Germans who critically - from a radical right-wing position - refer to the political, social and ethical values underlying the German system. However, the NR itself does not effectively undermine the stability of the constitutional system, nor do neo-Nazis. One cannot expect a fundamental transformation of the political scene in contemporary Germany any time soon.

However, the growing popularity of the extreme right should not be underestimated in this and other European countries. According to more recent sociological studies, people of low and medium material status (e.g. as many as $50 \%$ of workers in Austria and 30\% in the UK) are increasingly inclined to vote for populist and demagogic extremist right-wing parties in European parliamentary elections. This fact alone may raise certain concerns, although it is not yet a cause for alarm. In any case, there is no doubt that our continent is becoming increasingly 'brown', as Anna Wolff-Powęska noticed already in 2001. ${ }^{26}$ Throughout the two first decades of the 21st century, organisations of the radical right in France (Marine Le Pen's National Rally formerly known as the National Front), Belgium (Marco Santi's National Democratie and Frank Vanhecke's Vlaams Bloc, which was established in 2004), Austria (the late Jörg Haider's Freedom Party of Austria), Denmark (Kristian Thulesen Dahl's Danish People's Party), Portugal (André Ventura's Chega), Spain (Santiago Abascal's Vox), Switzerland (Alberta Rösti's Swiss People's Party), Italy (Matteo Salvini's League, formerly known as the Northern League), the United Kingdom (Adam Walker's British National Party), or in Greece (Nikolaos Michaloliakos' Golden Dawn) are becoming increasingly active. The extreme right is also becoming more vocal - and even more so than in the West - in Central and Eastern Europe, including Poland and Russia. All the groups referred to by this term preach similar propaganda slogans, which, according to the Austrian researcher of the extreme right Anton Pelinka, express 'nostalgia for socialism', i.e. the desire to introduce socialism with national characteristics combined with xenophobia. ${ }^{27}$ It is difficult to predict how this right wing is going to develop in the future - especially in the face of the European Union's organisational weakness and the massive influx of Asian and African refugees to our continent. It seems that the popularity of the NR is unlikely to decline, and may even increase and the political success of the Alternative for Germany seems symptomatic in this regard. While not explicitly part of the NR, it shows certain ideological similarities with the populist radical right. There is no doubt that the nationalism exhibited by the NR, with the added adjective 'new', will come to determine 
and define the propaganda face of the extreme right in the FRG for a long time to come.

\section{Notes}

1 More recent literature - cf Alice Brauner-Orthen, Die Neue Rechte in Deutschland. Antidemokratische und rassistische Tendenzen, (Leske and Budrich 2001); Margarete and Siegfried Jäger, Gefährliche Erbschaften. Die schleichende Restauration rechten Denkens, (Aufbau Taschenbuch Verlag 1999); Wolfgang Gessenharter, Rechtsextremismus und neue Rechte in Deutschland. Neuvermessung eines politisch-ideologischen Raumes? (Leske + Budrich 1998) and the Polish works: Walter Laqueur, Faszyzm. Wczoraj-dziś - jutro, (Da Capo 1998); Roger Eatwell, Faszyzm. Historia, (Rebis 1999).

2 Otto-Ernst Schüddekopf, Linke Leute von rechts. Die nationalrevolutionären Minderheiten und der Kommunismus in der Weimarer Republik, (Kohlhammer Verlag 1960).

3 Before 1945, the concept of the new nationalism was characterised by the socalled conservative revolution doctrine, which I describe in more depth in my book Niemieckie elity a hitleryzm. O stosunku rewolucyjnych konserwatystów do nazizmu w Rzeszy demokratycznej i hitlerowskiej, (Forum 1994).

4 Hans-Gerd Jaschke, 'Nationalismus und Ethnopluralismus. Zum Wiederaufleben von Ideen der "Konservativen Revolution"', (1992) Aus Politik und Zeitgeschichte. Beilage zur Wochenzeitung 'Das Parlament', (3-4), 3 et seq. Cf also Armin PfahlTraugheber, 'Konservative Revolution' und 'Neue Rechte'. Rechtsextremistische Intellektuelle gegen den demokratischen Verfassungsstaat, (Leske + Budrich 1998), 14.

5 Uwe Backes and Eckha Jesse, Politische Extremismus in der Bundesrepublik Deutschland, (Propyläen 1993), 69 et seq; Thomas Asshauer and Hans Sarkowicz, Rechtsradikale in Deutschland. Die alte und die neue Rechte, (C H Beck 1990), 27.

6 Backes and Jesse, (n 5), 67. Cf Klaus Schönekäs, 'Bundesrepublik Deutschland' in Franz Greß, Hans-Gerd Jaschke and Klaus Schönekäs (eds), Neue Rechte und der Rechtsextremismus in Europa: Bundesrepublik, Frankreich, Grossbritanien, (Vs Verlag Fur Sozialwissenschaften 1990), 218.

7 Günter Bartsch, Revolution von rechts? Ideologie und Organisation der Neuen rechten, (Herder 1975), 21.

8 Jens Mecklenburg (ed), Handbuch deutscher Rechtsextremismus, (Elefanten-Press 1996), 454.

9 Margret Feit, Die Neue Rechte in der Bundesrepublik. Organisation - Ideologie Strategie,(Campus Verlag 1987), 43; Karl-HeinzProhüber, Dienationalrevolutionäre Bewegung in Westdeutschland, (Deutsch-Europäischer Studien 1980), 37.

10 Mecklenburg, (n 8), 942; Richard Stöss, Parteien-Handbuch. Die Parteien der Bundesrepublik 1945-1980, (Westdeutscher 1984), 1948 et seq.

11 Jan Peters, Nationaler 'Sozialismus' von rechts, (Klaus Guhl 1980), 157.

12 Astrid Lange, Was die rechten lesen. Funfzig rechtsextreme Zeitschriften. Ziele, Inhalte, Taktik, (C H Beck 1993), 61 et seq.

13 They pay attention to two books, due to their nationalist content: Gerd-Klaus Kaltenbrunner, Die Herausforderung der Konservativen, (München 1974) and GerdKlaus Kaltenbrunner, Der Schwierige Konservatismus. Definitionen - Theorien Porträts, (Nicolai 1975). 
14 It is further developed in the article 'Odrodzenie ideologii rewolucyjnego konserwatyzmu po drugiej wojnie światowej’, (1996), 19, Studia nad Faszyzmem i Zbrodniami Hitlerowskimi, 170-171.

15 Pierre Krebs, Das unvergängliche Erbe. Alternativen zum Prinzip der Gleichheit, (Grabert 1981), 31.

16 Friedbert Pflüger, Deutschland driftet. Die Konservative Revolution entdeckt ihre Kinder, (Econ 1994), 11 et seq.

17 Kurt Lenk, 'Ein Gran Mussolini. Der publizistische Boom der Neuen Rechte', (1991), Die neue Gessellschaft/Frankfurter Hefte, (8), 728.

18 Bartosz Bolechów, Terroryzm w świecie podwubiegunowym. Przewartościowania $i$ kontynuacje, (Wydawnictwo Adam Marszałek 2002), 259. When it comes to the earlier research on this topic in the FRG cf. Richard Stöss, Die extreme Rechte in der Bundesrepublik. Entwicklung - Ursachen - Gegenmassnahmen, (Vs Verlag Fur Sozialwissenschaften 1989), 45-46.

19 Anna Wolff-Powęska, Polityczne i filozoficzne nurty konserwatyzmu w Republice Federalnej Niemiec, (Instytut Zachodni 1984), 110 et seq; Richard Saage, 'Neokonservatives Denken in der Bundesrepublik' in Irving Fetscher (ed), Neokonservative und 'Neue Rechte'. Der Angriff gegen Sozialstaat und liberale Demokratie in den Vereinigten Staaten, Westeuropa und der Bundesrepublik, (Beck 1983), 68.

20 Patrick C Moreau, 'Die neue Religion der Rasse. Der Biologismus und die kollektive Ethik der Neuen rechten in Frankreich und Deutschland' in Fetscher, (n 19), 121; Diethelm Prowe, 'National Identity and Racial Nationalism in the New Germany. Nazism versus the Contemporary Radical Right', (1997), 15, German Politics and Society, 1 et seq.

21 Cf Irenäus Eibl-Eibesfeldt, Der vorprogrammierte Mensch. Ererbte als bestimmender Faktor im menschlichen Verhalten, (Deutscher Taschenbuch Verlag 1976), passim; Gert Waldmann, Verhaltensforschung und Politik, (1973), Junge Kritik, 17.

22 Rafał Pankowski, Neofaszyzm w Europie Zachodniej. Zarys ideologii, (Instytut Studiów Politycznych PAN 1998), 79.

23 Jochen Termann, Von rechts nach links und zurück. Politische Ideologie des Rechtsextremismus nach dem II. Weltkrieg in Deutschland, Frankreich und Grossbritannien, (Institut für Zeitgeschichte Verlag 1993), 76.

24 Carl Schmitt, Politische Theologie. Vier Kapitel zur Lehre von der Souverenität, (Dunker \& Humblot 1934), 11.

25 Armin Mohler, "Carl Schmitt und die "Konservative Revolution"' in Helmut Quaritsch (ed), Complexio Oppositorum. Über Carl Schmitt. Vorträge und Diskussionbeiträge, (Dunker \& Humblot 1988), 37.

26 Anna Wolff-Powęska, 'Europa brunatnieje', Gazeta Wyborcza, (2001), 14-15 (VII), 16-18.

27 Grzegorz Sadowski, '12 brunatnych gwiazd', (2004), 28, Wprost, (III), 94-96. 